\title{
Heritage As a Source of Studies into Industrial History: Using Digital Tools to Explore the Geography of the Industrialization
}

\author{
Guillermo Esteban-Oliver*, Adrià San José* and Jordi Martí-Henneberg* \\ Department of Geography and Sociology, University of Lleida, Lleida, Spain
}

The main objective of this article is to explore the possibility of combining two very different sources in order to study the distribution of industrial activity throughout history. The traditional primary sources to use for this purpose are the official censuses on population and economic activity that have been conducted in the majority of countries since the

OPEN ACCESS

Edited by:

Josep Lladós,

Universitat Autònoma de

Barcelona, Spain

Reviewed by:

Joana Maria Pujadas Mora,

Centre for Demographic

Studies, Spain

Andreas Degkwitz,

Humboldt-Universität zu Berlin,

Germany

*Correspondence:

Guillermo Esteban-Oliver geoliver92@gmail.com;

Adrià San José

asanjopl7@gmail.com;

Jordi Marti-Henneberg

marti.henneberg@geosoc.udl.cat

Specialty section: This article was submitted to Cultural Heritage Digitization, a section of the journal

Frontiers in Digital Humanities

Received: 15 June 2017 Accepted: 14 September 2017

Published: 04 October 2017

Citation:

Esteban-Oliver G, San José A and Martí-Henneberg J (2017) Heritage As a Source of Studies into Industrial History: Using Digital Tools to Explore the Geography of the Industrialization.

Front. Digit. Humanit. 4:19.

doi: 10.3389/fdigh.2017.00019 mid-nineteenth century. However, the majority of these lack detail at the regional level and also with respect to the types of professional occupations that they quantify. In order to complement and profile these census data, we propose the use of another type of information which can also be quantified, but whose characteristics are very different. We refer to the industrial heritage sites identified in digital format in a given territory, which in this case is Catalonia, Spain. This innovative dataset was obtained using digital tools such as web scraping and data mining techniques. This type of historical information was used to check whether it is reliable and valid for interpreting the spatial impact of the introduction of industrial activity. The article also shows that the systematic identification of elements of industrial heritage offers a new and very useful source of information for interpreting the history of industrial geography.

Keywords: heritage, industry, occupations, census 1860, Spain, nineteenth century

\section{INTRODUCTION}

In economic history, there is a solid tradition of basing analysis on data obtained from official censuses. Certain countries were pioneers in developing this scientific knowledge about individuals and society, and soon began to publish censuses on a regular basis: the USA (1790), France (1795), and the UK (1801).

The Spanish censuses carried out between 1860 and 1930 were normally conducted at 10-year intervals. They therefore constitute a series which is of great value as a primary source of data. Even so, it was only after the emergence of international congresses that they started to unify their content in terms of which aspects to quantify (population, economy, education, etc.) and which methodology to follow (Elden, 2007; Randeraad, 2011). These sources have also been widely used by demographers, historians, and geographers, both for specific years and in order to carry out long-term time-series analysis.

Despite the fact that one of the objectives of censuses is to facilitate comparisons between countries and over time, this is not always possible. Differences between censuses can make it difficult. However, this variances offer some advantages: they make it easier to discover key phenomena that had not previously been explored by academics. An example of one of these would be the information that 
we exploit in this article; the 1860 "Professions, arts and crafts" census. This constitutes a point of reference in census work in terms of the geographic scale for which these data were published: 465 judicial districts, which were the administrative units used by the legal system. These subdivisions are used at the province level. ${ }^{1}$ They group together the 11,500 municipalities that existed in Spain back in 1842, many of which were subsequently merged to produce the 8,122 registered in 2015 . In later censuses, these data were no longer provided at the judicial district level but grouped into 48 provinces. In other words, they were grouped into units that are too big for conducting any form of detailed analysis.

The 1860 census is of great value for interpreting a Spain that found itself at the dawn of industrialization. As we shall see in later sections, these data have made it possible for us to detect major disparities between a number of judicial districts that were using new machinery (mainly located in Catalonia) and the rest of the country, where there was little industry and what did exist was often obsolete. However, as we shall later explain, the census data relating to industrial occupations do not completely reflect this duality. This is due to a lack of detail about the categories into which the data were divided. Thus, while textile activity in Galicia-which had tended to be predominantly traditional and artisan in character-was about to go into decline, the presence of textile machinery in Catalonia was about to enable it to absorb the Spanish market (Germán, 2001). We therefore need other sources of information in order to contrast the available data on employment during periods for which GDP or industrial output data have yet to be calculated.

In this article, we have used a new source that we consider particularly relevant; this is an indicator of manufacturing activity based on the number of industrial heritage sites that have currently been identified. These sites may be located within the territory studied and classified into categories according, among other considerations, to the type of industry involved and its period of relevance.

Our hypothesis is that the industrial intensity indicated by the censuses is confirmed by the presence of industrial remains. This type of information also contributes much greater detail about the size, specialization, and location of industrial activity within the territory studied. As we shall see, this permits a type of locational analysis that makes it easier to identify the factors that most influenced the introduction of what were the most innovative activities in 1860; these were industrial activities.

In this first section, we situate the position of Catalonia within the wider context of Spain. The first available data about industrial activity are those provided by the 1860 census. This information enables us to show that Catalonia was already one of Spain's industrial poles by this time. Here, we also establish the Spanish context of that time and analyze the technical validity of the source. We then finish by considering the subsequent development of regional disparities in Spain, based on available studies.

${ }^{1}$ We have data for a total of 48 provinces. This excludes the Canary Islands, for which no consistent information is available.
If we compare the evolution of Spain's per capita GDP with that of the rest of Western Europe, it is possible to observe that between 1860 and 1914 it became increasingly distant from the European average, falling from 0.63 to $0.58 \%$ of the mean value for Europe. ${ }^{2}$ Even so, if we analyze the evolution of Spain's per capita GDP between 1860 and 1914 in purely national terms, we find that it increased by $163 \%$ (a progression that was comparable with that seen in other European states). This type of rise had never been seen before and was essentially linked to the first stages of industrialization. With respect to the demographic context, internal migration flows were low and mainly occurred over relatively short distances and on a temporary basis (Silvestre, 2007). Generally speaking, in Spain, the factors of production lacked mobility.

As a result, based on the Heckscher-Ohlin model, it would be expected to find the industrialization process mainly concentrated in the regions that had the greatest capital and market endowments. ${ }^{3}$ In 1860, the most industrialized regions were still those that traditionally had the biggest accumulations of financial and human capital and also the largest markets. Gradually, and as Spain industrialized and transport costs fell, these areas absorbed the less competitive industry from other regions. While this was taking place, economies of agglomeration started to kick in. This resulted in centripetal and centrifugal forces colliding to eventually produce the present situation, in which, except in Andalusia and some of the more isolated parts of the interior, the regions that were most economically developed in the 1860s, remain the most advanced ones today (Tirado et al., 2016).

Spain's nineteenth century industrialization produced unprecedented regional disparities (Rosés et al., 2010). These were largely linked to the industrial growth that certain specific regions experienced in this century. This development contrasted with much slower progress in agricultural areas in most of the country. These zones could not rise to the challenge that industrialization posed until the middle of the twentieth century (Tirado et al., 2016). ${ }^{4}$ Although innovative activities have since spread, this situation of industrial polarization remains crucial for understanding the regional dynamics that we observe today. Thus, most of the areas that had powerful industrial sectors in 1860 continue to stand out today, while those that were most dependent on agriculture have progressively lost relevance. The exceptions to this rule are the areas that have recently developed tourism functions, as they have managed to maintain or even gain dynamism (Parejo, 2004). Comparing the areas where the weight of the industrial sector was

${ }^{2}$ This is the average of 12 Western European countries: Austria, Belgium, Denmark, Finland, France, Germany, Italy (central and north), Netherlands, Norway, Sweden, Switzerland, and the UK. These data were extracted from the Maddison Project: $<$ http://www.ggdc.net/maddison/maddison-project/home.htm>.

${ }^{3}$ Heckscher-Ohlin is a general equilibrium model that mathematically develops David Ricardo's early 19th century theory of comparative advantage. This model appeared for the first time in 1933, in Ohlin, Bertil: "Interregional and international trade" (Ohlin, 1933)

${ }^{4}$ The Catalan coast, much of the Basque Country and some isolated zones in Asturias, Alcoy, and Malaga were some of the first areas into which modern industry was introduced. It should be noted that the "rest" includes a large number of regions with different growth rates. In any case, their industrial growth was slow compared to that of the Basque Country and Catalonia. 
relatively high in the past with those where it is important today, we observe two interesting phenomena. The first relates to the coincidence between what were the most dynamic areas in 1860 and remain so in the present (Figure 1). ${ }^{5}$ The second is that the areas that have lost most potential are the provinces of Andalusia, Ciudad Real and Murcia, which have been replaced by provinces located in the Ebro Valley (Tirado et al., 2016).

It has been important to use contributions from the field of Economic History in order to understand and identify some of the dynamics involved in the industrialization of Spain. In the international literature Williamson (1965) followed the lead of Kuznets (1955) in arguing that, at the beginning of modern economic growth, industry tended to agglomerate around very specific poles which caused major regional disparities. Even so, these differences tended to disappear in the long term. These theories were later tried and tested using historical regional data from countries such as the UK and France, where the results obtained seemed to support Williamson's hypotheses. However, since the 1980s and 1990s, it has been possible to observe a slight increase in regional disparities which could refute the idea of long-term convergence. Similarly, it is necessary to bear in mind the fact that this dynamic of regional disequilibria has been relatively variable according to the country analyzed; we do not find identical patterns of evolution in the regional disparities of the UK and Spain.

${ }^{5}$ Or closely related neighboring provinces, for example: Madrid-Guadalajara and Valencia-Castellón.
In this respect, it is essential to refer to a work that Nadal (1975). This author claimed that, with the exception of the Catalan and Basque poles, nineteenth century Spain was an essentially an industrially barren country. The reasons for this were a precarious national market and the very limited availability of capital. Another very important work was published by Tortella (1995). This study focused on the instability of the institutions of that time, and helps us to understand the reasons for the failure of the industrial revolution in Spain. Even so, these-and many other works-did not quantify or explain the factors responsible for the location of Spain's very limited industrialization in the specific areas in which it occurred. Following in the tracks left by these texts, a number of original articles have been published that have progressively improved our understanding of industrialization in Spain. Many of these have been based on previously unexplored regional data, modern statistical techniques and new theoretical frameworks.

These contributions have proved of incalculable value for providing a greater variety of theories and subtle nuances relating to the development of industrialization in nineteenth century Spain. In general, the results obtained have been similar to those found in other neighboring European states (albeit with a certain time delay). In Figure 2, it is possible to observe the great increases in regional disparities that took place during the first stages of industrialization, from 1860 to 1920 , followed by their decline from the mid-twentieth century until the 1980s and then a new increase from then until now (Tirado et al., 2016). The factors that conditioned these dynamics have been studied in numerous publications including Tirado et al. (2002), Martínez-Galarraga
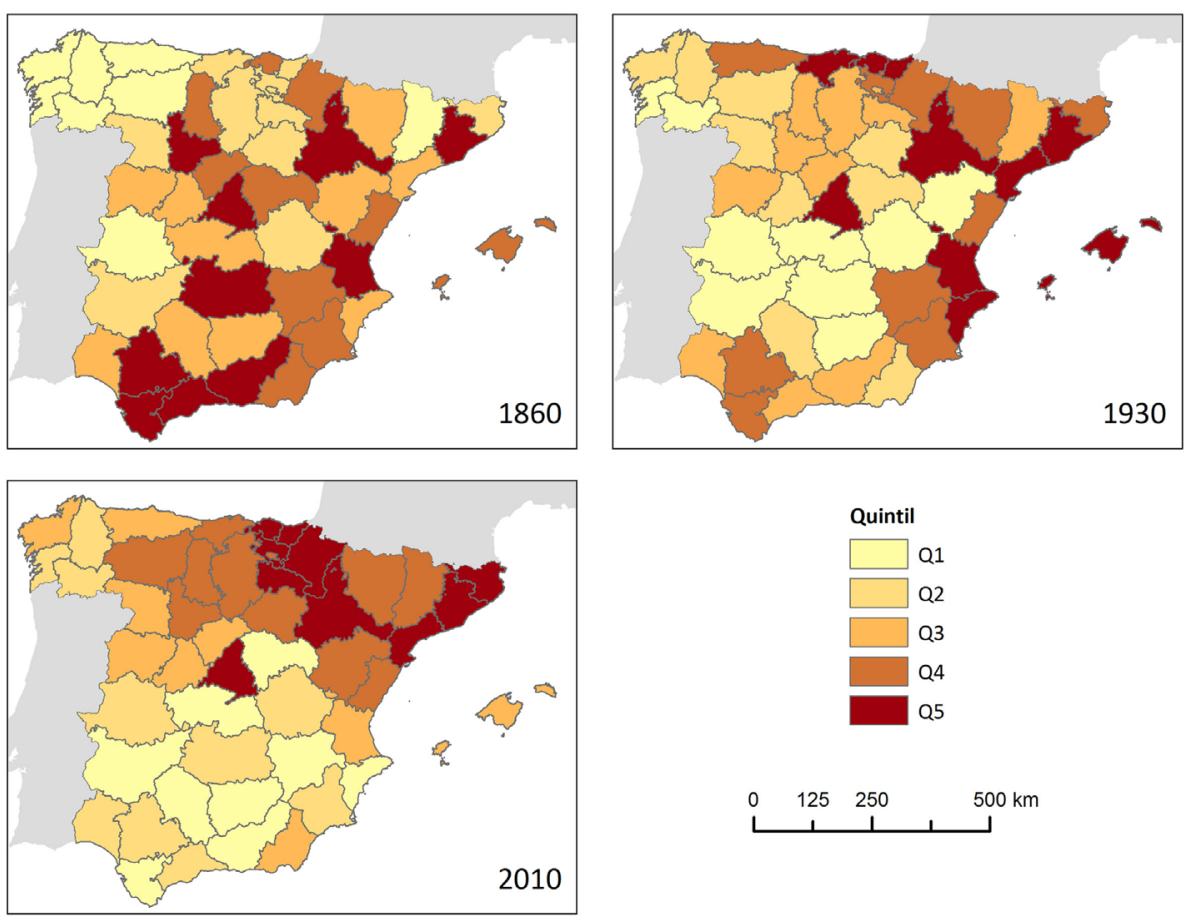

FIGURE 1 | Evolution of quantiles of per capita GDP by Spanish province (NUTS3). The regions (NUTS) are grouped by quintiles. The darker the color representing the province, the richer it is. No permission is required for the use and reproduction of this data. Source: Tirado et al. (2016), p. 96. 


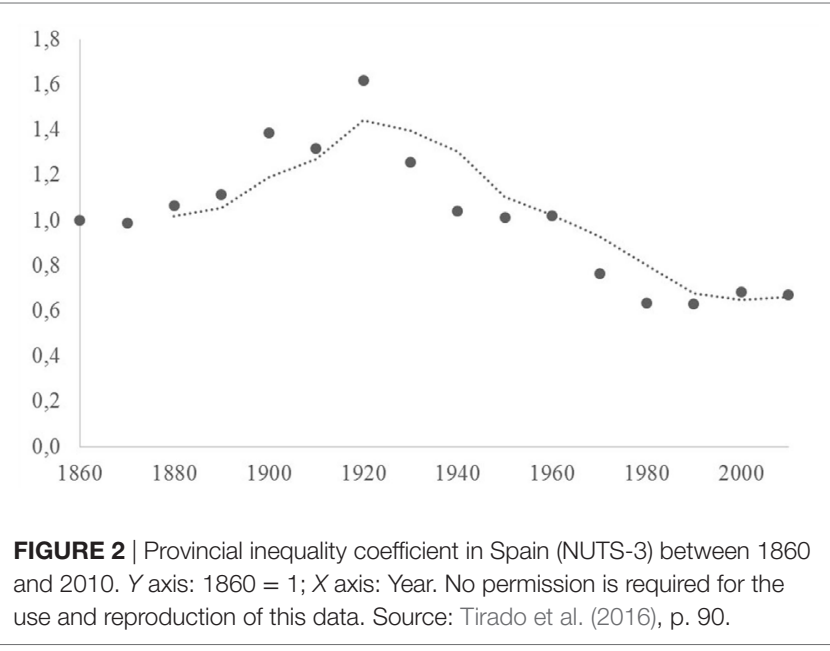

(2012), and Beltrán-Tapia et al. (2016). These texts conclude that the main factors responsible for the heterogeneous spatial location of industry within Spain predated the country's industrialization (and included the size of the market, the strength of the agricultural sector and/or the amount of capital accumulated). It is also true that industrialization and its associated dynamics based on economies of agglomeration exacerbated these differences. Some of the other texts that have analyzed the conditioning factors that could have influenced the dynamics behind regional disparities include Pons et al. (2007), Ayuda et al. (2010), and Martínez-Galarraga et al. (2015).

If we focus on Catalonia and analyze Figure 2, we observe a relatively high (but not too much) economic development in 1860. We can observe that although this Autonomous Community is now one of the richest in Spain, its difference with respect to the rest of Spain does not seem to be so great. This seems to run contrary to Catalonia having already been the largest industrial agglomeration in Spain in 1860 (Parejo, 2004). However, if we move down a level of aggregation and analyze the distribution of income at the provincial level, the situation seems to become clearer. In 1860, we find the Catalan industrialization in its infancy and mainly limited to the province of Barcelona and adjacent areas (Esteban-Oliver, 2017). As a result, Barcelona province appears in the quintile with the highest incomes in Spain whereas the provinces of Tarragona and Lleida are in the third (corresponding to the average for Spain). Finally, Lleida province appears in the worst quintile, appearing as one of the poorest areas in Spain in 1860. This heterogeneous distribution of income and industry within the Catalan territory conditioned the overall result for the region and obscured the great economic and industrial development in the province of Barcelona. As a result, it was necessary to wait until later in the century for industrialization to spread across the whole region and with it industrial heritage. As previously commentated, this relation of regional disparities in Spain (which was exacerbated by industrialization) reached its maximum expression in the 1920s. In that decade, the per capita GDP of Catalonia was four times greater than in the poorest areas of Spain. This difference then progressively declined until the 1980s (Rosés et al., 2010, p. 249). From then on, and as highlighted by Tirado et al. (2016), the advantage of the richest regions has once again tended to increase, although not to a very important extent. At present, Catalonia remains one of the richest regions in Spain and, although far from enjoying the pre-eminence of the end of the nineteenth and early twentieth centuries, its industrial heritage located within its territory provides a clear reminder of the industrial revolution in nineteenth century Spain.

After the considerations that form this introduction, the next section of this article is dedicated to locating the problem within the context of Spain based on an analysis of the 1860 census. Particular attention has been given to the characteristics of the 1860 census and to the very special possibilities for analysis that derive from it. In the last part of the second section, we present the methodology that we used to create and exploit a database on the industrial heritage of Catalonia. This database consists of around 2,000 geolocated industrial sites for which we also have descriptive information. Combining this source with that of the 1860 census has allowed us to explore the possibilities of combining the two. This is the subject that we develop in the third section, which is about the results obtained. This article concludes with a presentation of future lines of work that could originate from this proposal. Although here we have analyzed the case of Catalonia, this research has been designed in such a way as to allow the exportation of the same approach to any other territory for which similar data are available.

\section{MATERIALS AND METHODS}

The methodology used to develop this research consisted of an analysis to correlate industrial occupations with data about industrial heritage sites. We will start by first describing the methodology that allowed us to compile a database for industrial occupations in 1860. Then we will describe how we created a complementary database on industrial sites. As a result, we were able to analyze whether the two datasets were correlated and the extent to which they were able to provide detailed georeferenced data. ${ }^{6}$

\section{Material and Methods for the 1860 Census}

We chose the 1860 census ("Profesiones, artes y oficios") for various reasons. ${ }^{7}$ The first related to the availability of data for the judicial district level. The second reason for choosing this census was that it represents a key period in Spanish economic history, as 1860 coincided with the beginning of the country's industrialization. As we will see in the next section, Spain's regional disparities in terms of industry were already appreciable but not very big in 1860. The reason for this was that these industries were mostly based on traditional manufacturing oriented toward serving local markets. In contrast, the introduction of new forms of mechanization was only just beginning and mostly confined to Catalonia.

${ }^{6}$ For this methodology, we heavily relied on the ideas that Crafts, N. y Nikolaus W. used in their 2014 study: "The location of the UK cotton textiles industry in 1838: A quantitative analysis" (Crafts and Wolf, 2014).

${ }^{7}$ Other articles that have studied and/or used this census are Gozálvez and MartínSerrano (2016) and Beltrán-Tapia et al. (2015). 
The 1860 census was undertaken within a context of political and economic change due to the need to carry out reforms in order to consolidate the liberal state. The government needed reliable information about population and economic activity to pursue its proposed reforms. ${ }^{8}$ A precedent to the census could be found in that of 1857 census, which had been conducted using updated techniques but whose lack of previous population references limited its reliability (Muro et al., 1996). This led to the need for a new census: the 1860 census (Melón, 1951). This new census was motivated by the conclusions from a number of international congresses. These meetings recommended carrying out this kind of studies once every 10 years, and preferably in years finishing in 0, following the American example. ${ }^{9}$

Thanks to the experience acquired from conducting the 1857 census that of 1860 was much more accurate and considerable gains were made in terms of its content. These included the incorporation of a number of new socioeconomic variables which provided better quality information about population structure and the occupations, and levels of education of Spanish citizens. The novelty introduced into this census consisted of the classification of citizens by their "professions, arts and crafts" and the provision of this information at the "Judicial District" level. The civil servants charged with compiling this census and carrying out the associated fieldwork were very rigorous and diligent (Gozálvez and Martín-Serrano, 2016). They revealed the difficulties that they had had to overcome when classifying the different occupations of citizens and especially of those who lived in rural areas. The reason for this was that many people had different activities, which made it very difficult to assign a specific function or job to every person who had employment. Those responsible for the census expressed their concerns in the following terms: “... major obstacles had to be overcome in order to offer the public-for the very first time-a picture of the national population classified according to their jobs, professions, arts and crafts (...). It is necessary to consider that this is a computation that is still wanting in terms of greater accuracy but which constitutes an attempt to gather data that can serve as a starting point." These civil servants also observed that despite some of the difficulties encountered, the result was consistent and could serve as a basis for other censuses and studies.

In order to overcome these problems, we applied a series of quality checks. These prepared the data for use in statistical treatments and international comparisons. In Esteban-Oliver (2017), we explained in detail the methodology used for the elaboration, interpretation and checking of this new database. As a result, in this article we have not presented the complete elaboration process for the 1860 census. We have simply presented a brief

\footnotetext{
${ }^{8} \mathrm{~A}$ precedent to this is the "Floridablanca Census," which was the first Spanish census prepared using "modern statistical techniques." In later studies, this census was used as the main point of reference.

${ }^{9}$ In subsequent 19th century censuses (1877 and 1887), the census years ended in "7," following the example of the Floridablanca, Godoy and 1857 censuses. The practice of publishing censuses in years ending in "0" was, however, reinstated from 1900 to 1970.
}

summary of the methodology employed, which we shall now proceed to explain.

First, we made a series of quality checks to ascertain the reliability of the 1860 census. The most important findings from this initial investigation were as follows:

In certain parts of Spain we found evidence of a tendency to overestimate the percentage of the active population with respect to the total population. Even so, and as indicated by Esteban-Oliver (2017), this problem was limited to several very specific legal districts (located in the north-east of the peninsula).

We also decided to include the female population because this helped to improve the consistency of the database. What is more, adding information about the female population enriched the census data.

In addition, we improved on the classification that had originally been established for the census. We eliminated "professions" that did not represent the active population. We also renamed and reclassified all of the different professions based on HISCO. ${ }^{10}$ This reclassification provided our database with greater consistency and also allowed us to make international comparisons.

\section{Materials and Methods for the Industrial Sites Database}

In this section, we outline an innovative approach to identify the industrial heritage of Catalonia (Figure 3). Although this article focuses on the specific case of Catalonia, this following procedure-which is based on data mining techniques-could be directly applied to a number of different scenarios. What follows here is therefore, in fact, a methodological proposal to help identify industrial heritage.

The architectural heritage inventory of Catalonia is composed of Catalan buildings and constructions-or individual parts of them—of artistic, architectural and/or historic interest. ${ }^{11}$ This initiative, which dates from 1982, was supported by the "Generalitat de Catalunya" with the aim of promoting the study of the cultural heritage of this region. ${ }^{12}$ In total, just over 28,000 monuments are included in this inventory. The interest of the public institutions in identifying and cataloging heritage stems from a long-standing popular tradition in the region. In fact, numerous associations fight for the conservation of Catalonia's cultural heritage and there are also several blogs which share this mission.

Furthermore, the Heritage Department of the Generalitat de Catalunya recently reached an agreement to provide Wikipedia

\footnotetext{
${ }^{10}$ As a reference, I have used the "International Institute of Social History" or HISCO. The database which I shall now go on to present has provided me with the input required to reclassify the professions used in the census: $<$ https://socialhistory.org/en/projects/hisco-history-work>.

${ }^{11}$ Inventari del Patrimoni Arquitectònic de Catalunya (Catalan heritage inventory): $<$ http://cultura.gencat.cat/ca/departament/estructura_i_adreces/organismes/ dgpc/temes/patrimoni_arquitectonic/inventari_del_patrimoni_arquitectonic_ de_catalunya/ $>$.

${ }^{12}$ Generalitat de Catalunya refers to the government of the Regional Autonomy of Catalonia.
} 

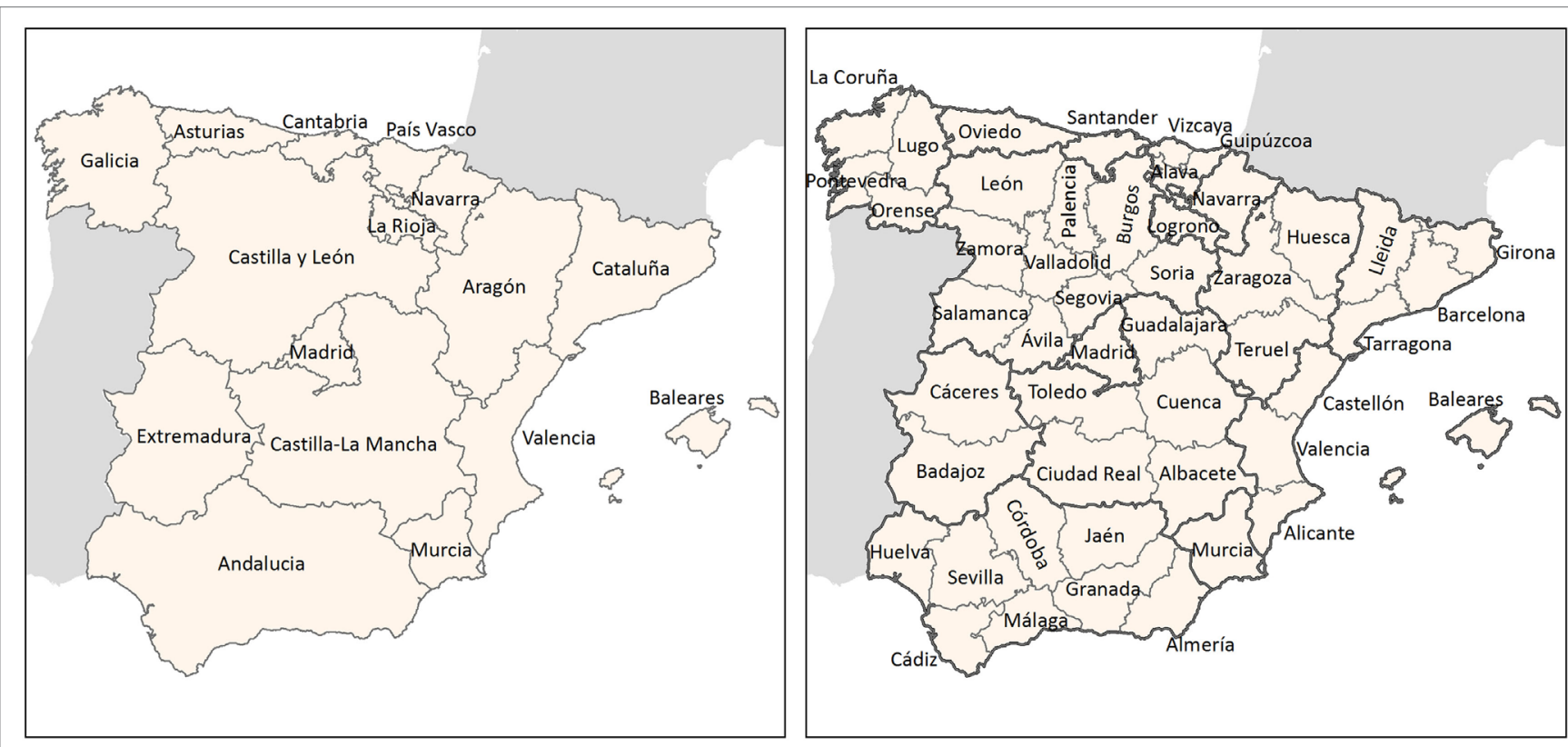

FIGURE 3 | Regions and Provinces in Spain. Source: Own research.

with the data corresponding to this inventory. The Wikipedia Community then enriched the data by adding the GPS coordinates of each monument and currently ensures that these data are correct and kept up to date. In fact, a specific Wikipedia page has been built listing local monuments of interest in almost all of the 948 municipalities in Catalonia. Each of these pages includes a table containing the following fields: the name of the monument, the type of protection the monument receives, the architectural style, the approximate date of construction, the location, the GPS coordinates, the official monument reference code, and images of the building in question.

At the same time, the Catalan Government set up a search engine to help citizens explore the architectural heritage of Catalonia. ${ }^{13}$ This webpage provides a short description of each monument and also information about its associated economic sector and any other activities that it was used for, which is the kind of information that is not available from Wikipedia.

We were interested in selecting buildings which belonged to the "Industrial" sector category, but encountered two problems. On the one hand, the search engine does not provide users with a filter to select industrial elements. On the other, the GPS coordinates of the monuments, which are crucial for representing this information on a map, are not available from this webpage. In order to identify and map the industrial monuments of Catalonia we therefore had to combine information from two different sources. We needed to obtain a list of all the monuments in the Catalan architectural heritage inventory and their GPS coordinates from Wikipedia and to classify them according to their respective sectors using the search engine of the Catalan Government.

${ }^{13}$ Monument dataset: $<$ http://invarquit.cultura.gencat.cat/cerca $>$.
TABLE 1 | Results from the 1860 "Profesiones artes y oficios" census.

\begin{tabular}{|c|c|c|c|c|}
\hline $\begin{array}{l}\text { Level of } \\
\text { analysis }\end{array}$ & Classification & $\begin{array}{l}\text { Primary } \\
\text { sector }\end{array}$ & $\begin{array}{l}\text { Secondary } \\
\text { sector }\end{array}$ & $\begin{array}{l}\text { (Industrial } \\
\text { secondary) }\end{array}$ \\
\hline \multirow[t]{2}{*}{ State } & Total population & $4,255,120$ & $1,211,339$ & 531,570 \\
\hline & \% population & 62.9 & 17.9 & 7.8 \\
\hline \multirow[t]{5}{*}{$\begin{array}{l}\text { Judicial } \\
\text { district }\end{array}$} & $\begin{array}{l}<10,000 \\
\text { inhabitants }\end{array}$ & $69.3 \%$ & $12.71 \%$ & $7.1 \%$ \\
\hline & $\begin{array}{l}\text { From } 10,000 \text { to } \\
25,000\end{array}$ & $67.2 \%$ & $15.4 \%$ & $7.1 \%$ \\
\hline & $\begin{array}{l}>25,000 \\
\text { inhabitants }\end{array}$ & $55.2 \%$ & $23.3 \%$ & $9.5 \%$ \\
\hline & Madrid & $15.5 \%$ & $38.8 \%$ & $12.6 \%$ \\
\hline & Barcelona & $12.8 \%$ & $58.6 \%$ & $29.1 \%$ \\
\hline $\begin{array}{l}\text { Level of } \\
\text { analysis }\end{array}$ & Classification & $\begin{array}{l}\text { Tertiary } \\
\text { sector }\end{array}$ & $\begin{array}{l}\text { Total for all } \\
\text { sectors }\end{array}$ & Observations \\
\hline \multirow[t]{2}{*}{ State } & Total population & $1,298,485$ & $6,764,944$ & 464 \\
\hline & $\%$ population & 19.9 & 100 & 464 \\
\hline \multirow[t]{5}{*}{$\begin{array}{l}\text { Judicial } \\
\text { district }\end{array}$} & $\begin{array}{l}<10,000 \\
\text { inhabitants }\end{array}$ & $17.9 \%$ & $100 \%$ & 157 \\
\hline & $\begin{array}{l}\text { From } 10,000 \text { to } \\
25,000\end{array}$ & $17.3 \%$ & $100 \%$ & 256 \\
\hline & $\begin{array}{l}>25,000 \\
\text { inhabitants }\end{array}$ & $21.4 \%$ & $100 \%$ & 39 \\
\hline & Madrid & $45.6 \%$ & $100 \%$ & 1 \\
\hline & Barcelona & $28.52 \%$ & $100 \%$ & 1 \\
\hline
\end{tabular}

Source: Data extracted from Comisión Estadística del Reino (1860).

This table presents the sectoral distribution of employment in different geographical levels. We display from the State aggregation level to the judicial party one. The judicial party aggregation is divided by population levels and we present separately the Madrid and Barcelona results.

To do this, we created a program which consulted the Catalan Government search engine to obtain relevant data about each of the 28,000 monuments listed in the Wikipedia municipality 
pages and to check whether these monuments belonged to the "industrial" sector category. Following this procedure, we readily identified almost 2,000 industrial sites. Once this had been done, we analyzed the names and descriptions of all the monuments that we had discarded in order to check for clues as to whether they had ever housed any key industrial activities. We searched for names like "industry," "textile," "chimney," "furnace," "kiln," and "mill" as they would have suggested previous industrial sector activity. However, this last step could also generate some erroneous results as our program might be led to believe that a church in a road called Mill Street belonged to the industrial sector if the key word "mill" appeared in its name or description. We took this into account and tried to prevent this from happening by making more intelligent searches. Although some errors may have been possible, we remain confident about the validity of our results. With the help of this second iteration, we slightly extended our list and eventually identified a total of 2,439 industrial monuments in Catalonia.

As stated in the Section "Introduction," our intention was to draw data from two complementary sources in order to study industrial activity in 1860 . These sources were data from the 1860 census and from the catalog of the industrial heritage sites of Catalonia. In order to establish a reasonable comparison between these datasets, we needed to first determine which Catalan monuments-out of the
2,439 previously identified-had been built before 1860 . As previously explained, for each of these industrial monuments we had an approximate date of construction, so we could filter them in order to obtain a reliable picture of industrial activity in Catalonia in 1860. We have to bear in mind that this resulting selection may have contained some minor errors due to the inexact information that we had to deal with. Nonetheless, we are confident that this methodology provides a reliable picture of industrial activity in Catalonia in 1860.

Our objective was to independently map our two sets of data in order to compare them and then determine whether industrial sites offer an accurate picture of industrial activity in Catalonia.

After reviewing the methodology used in this article, we proceed to present our results.

\section{RESULTS}

The data that we classified from the 1860 census allowed us to undertake a wide range of analyses. Here, we shall simply describe the data so that they can be complemented with data about industrial sites obtained from other sources. This is because our objective is to prove-through a descriptive analysis-that industrial heritage data can be a great complement while analyzing regional economic structures.

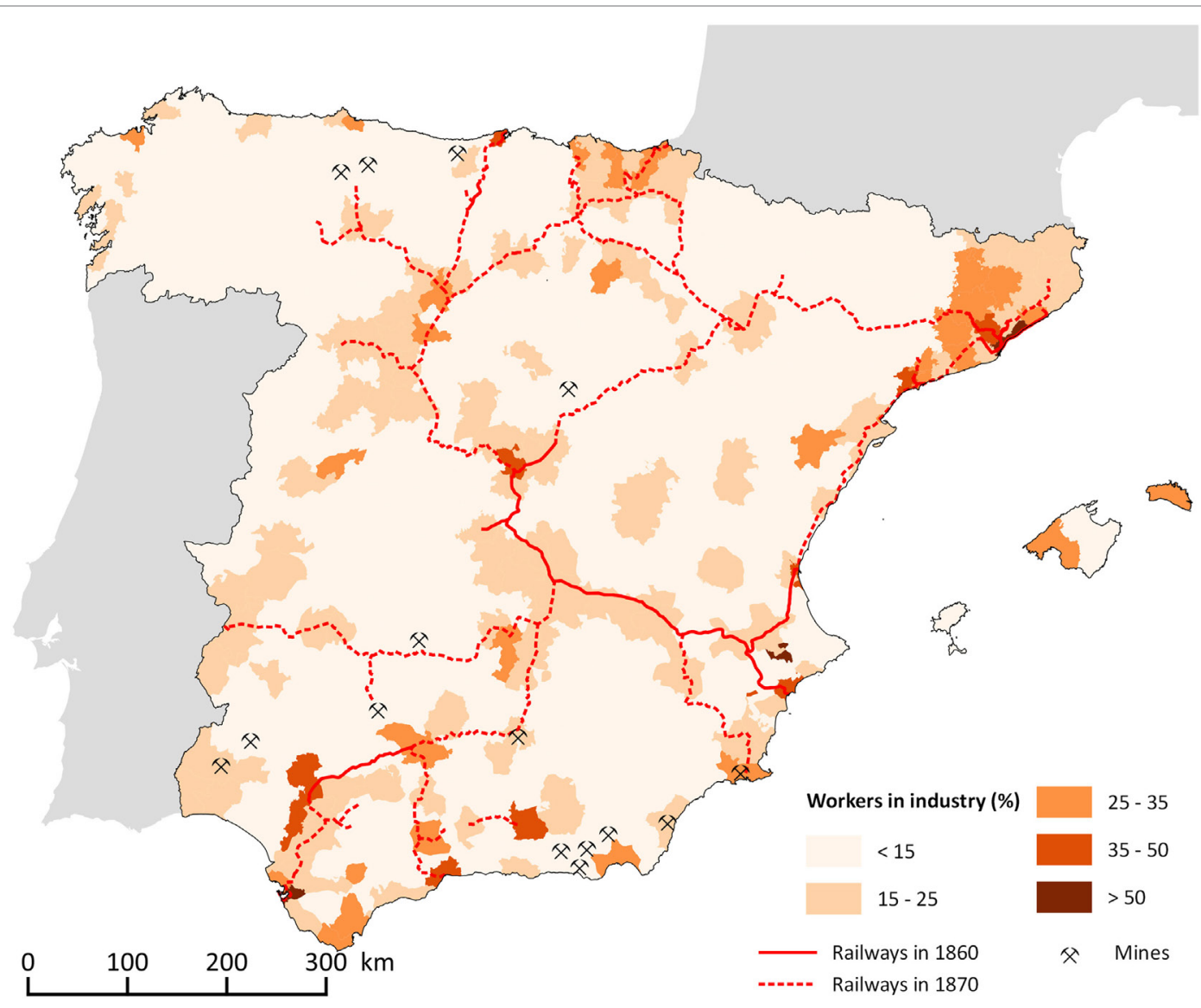

FIGURE 4 | Percentage of industrial workers and artisans over the total occupied population in Spain in 1860, by judicial district. Source: Own research. 


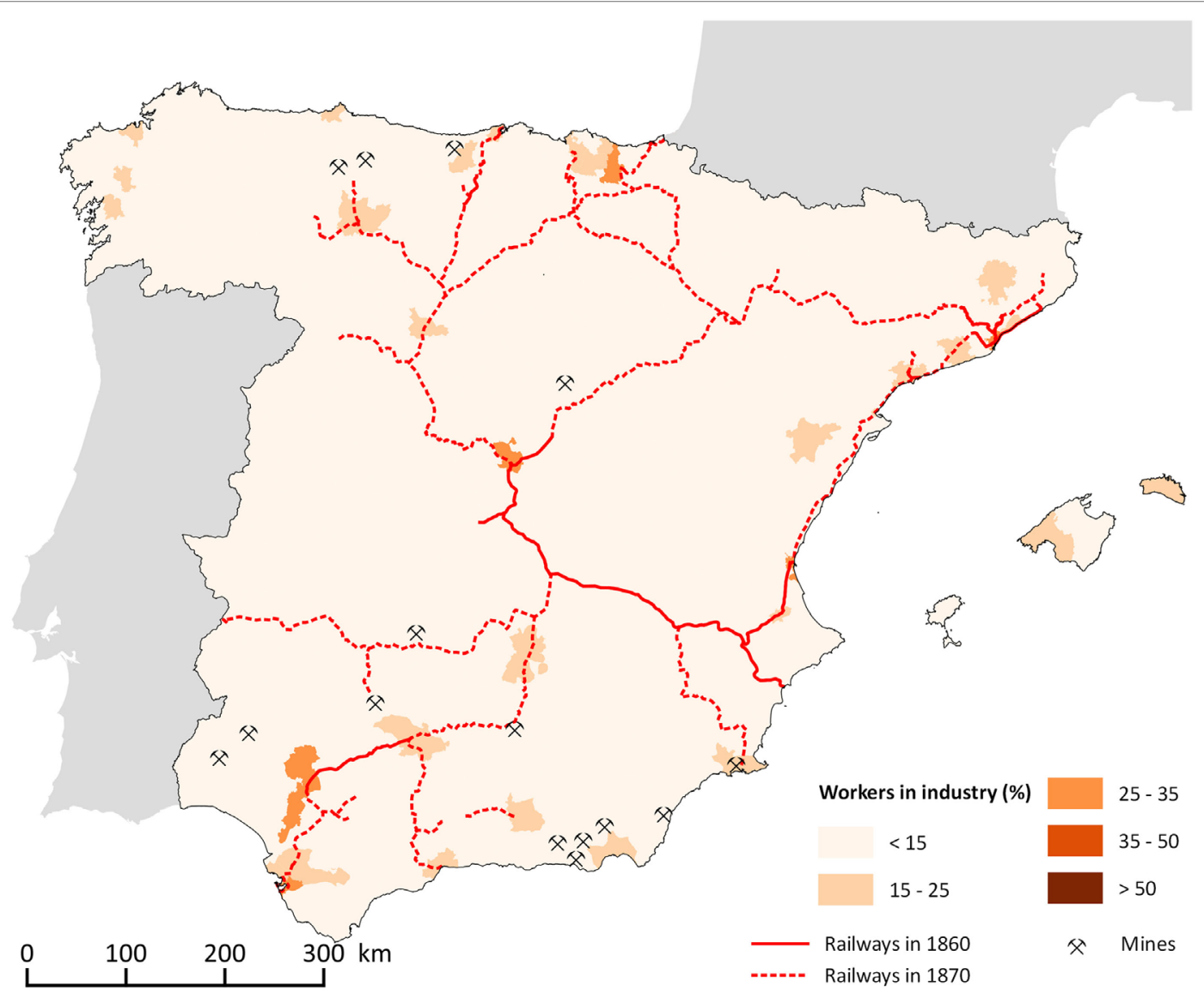

FIGURE 5 | Percentage of industrial workers over the total occupied population in Spain in 1860, by judicial district. This figure does not include artisans. Source: Own research.

Table 1 presents the census data results by sector. The population employed in the primary sector was up to $62.90 \%$. This was an expected result for an eminently agrarian country. The secondary sector employed $17.90 \%$ of the total workforce. Finally, the tertiary sector accounted for $19.90 \%$ of total, which is a very low percentage by modern standards, but would have been usual for a nineteenth century economy. ${ }^{14}$

We present maps in Figures 4-6 in order to observe these results in graphic form and at the judicial district level. In Figure 4, we can observe an uneven distribution of industry within the territory. These results show that Catalonia already stood out as the most industrialized region in Spain. It is also possible to appreciate that, with the exception of this Catalan pole and certain areas of Andalucía, Alicante, Madrid, and the Basque Country, the indicators relating to industrial employment are low, reflecting an eminently agricultural country. Although this text specifically focuses on Catalonia, a detailed regional analysis for the whole of Spain, based on this same census data, can be found in Esteban-Oliver (2017).

${ }^{14}$ If we compare our data with those of Prados de la Escosura (2003), we observe almost identical outcomes. Our results showed slightly higher values in the secondary sector and lower ones in the agricultural and services sectors.
In contrast to the previous map, Figure 5 only presents data relating to employment in the industrial sector. It does so without taking into account artisans, most of whom were engaged in manual industrial work which was considered preindustrial. In this way, it is possible to more clearly appreciate which areas were significantly dedicated to the more modern, mechanized industry. It can be seen that Catalonia was the area with the greatest concentration of this type of activity in 1860. Finally, and to conclude this series on Spain, Figure 6 presents absolute figures for total employment in industry. The map complements the information presented in Figure 2 and identifies the main nuclei (Catalonia, Valencia, and Madrid) and those with the largest concentrations dispersed along Spain's north coast and in Andalucía and the interior.

We have seen that by 1860 Catalonia was already the main industrial nucleus in Spain, although it contained significantly different internal realities. We dedicate the remaining part of this section to a more detailed analysis of the distribution pattern of industry in Catalonia. We should remember that to do this we did not only rely on census data, but also information about its industrial sites.

Figure 7 combines all of the previous data relating to the 1860 census. It confirms that the results show significant internal differences because the judicial district data break down aggregated information at the province level. The industrial sector employed 


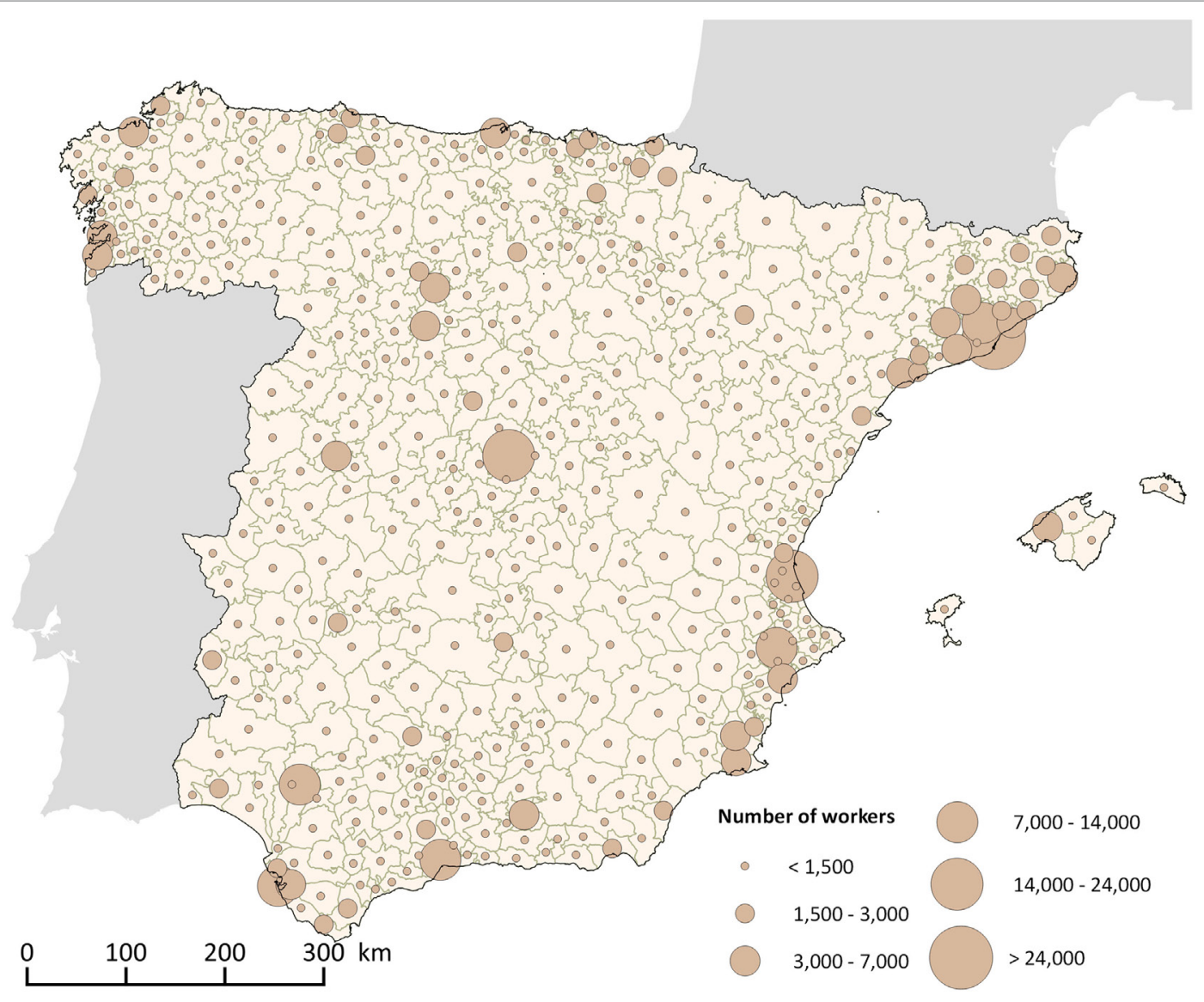

FIGURE 6 | Total number of industrial workers in Spain in 1860 by judicial party. This figure does not include artisans. Source: Own research.

almost $40 \%$ of the working population in Barcelona province, but only around $20 \%$ in the provinces of Tarragona and Gerona, and even less in Lleida. The reason for this disparity was that Barcelona concentrated the greatest levels of specialization and industrial agglomeration in Spain, both in terms of traditional and modern industry. ${ }^{15,16,17,18,19}$ If we observe in more detail, we see that the judicial districts with the highest levels of industrial specialization were those of Barcelona (which possessed 58.64\% of the total industrial workforce), its neighboring districts and the Reus-Tarragona nucleus. The result for the judicial district

\footnotetext{
${ }^{15}$ Data from The Maddison-Project, collaborative research on historical national accounts. Digital Repository: http://www.ggdc.net/maddison/maddison-project/ home.htm 2013 version.

${ }^{16}$ Departament de Cultura de la Generalitat de Catalunya. Direcció General d'Arxius de Arquitectura. Inventari del Patrimoni Arquitectònic de Catalunya. Gencat Digital repository (2017): http://cultura.gencat.cat/ca/departament/ estructura_i_adreces/organismes/dgpc/temes/patrimoni_arquitectonic/ inventari_del_patrimoni_arquitectonic_de_catalunya/.

${ }^{17}$ European Route of Industrial Heritage (ERIH). Catalan Dataset. Digital repository 2017: http://www.erih.net/i-want-to-go-there/.

${ }^{18}$ Generalitat de Catalunya. Patrimoni i Arquitectura. Monument dataset. Gencat Digital repository 2017: http://invarquit.cultura.gencat.cat/cerca.

19 “International Institute of Social History" or HISCO: <https://socialhistory.org/ en/projects/hisco-history-work>.
}

of Barcelona is particularly significant as it was the second highest register of industrial specialization in Spain, after Alcoy in the province of Alicante. If we put these results into the context of Southwest Europe (Díez-Minguela et al., 2017), it becomes clear that this was a very relevant industrial area. In 1860, the breakdown of these industries back was basically shared by the textile, agrofood, and paper sectors.

To contrast our approach descriptively, we completed our census database with the results obtained from identifying industrial sites in Catalonia in 1860. In line with our hypothesis, we expected to find a high correlation between the areas with the highest levels of industrial agglomeration and the number of Heritage Industrial sites.

The maps in Figures 8 and $\mathbf{9}$ confirm this idea. We observed a high correlation between the most industrially specialized judicial districts and the greatest concentrations of heritage. We also noted that the majority of the factories that were working in 1860-and whose remains have survived until the present day-were located in the judicial districts of the provinces of Barcelona, the coast of Tarragona, and their immediate vicinity, whereas in more distant areas (such as Lleida Province, the Pyrenees, and the interior of Tarragona Province) a lot fewer existed and, as a result, have survived. It is necessary to explain that these data can only be used as general indications 


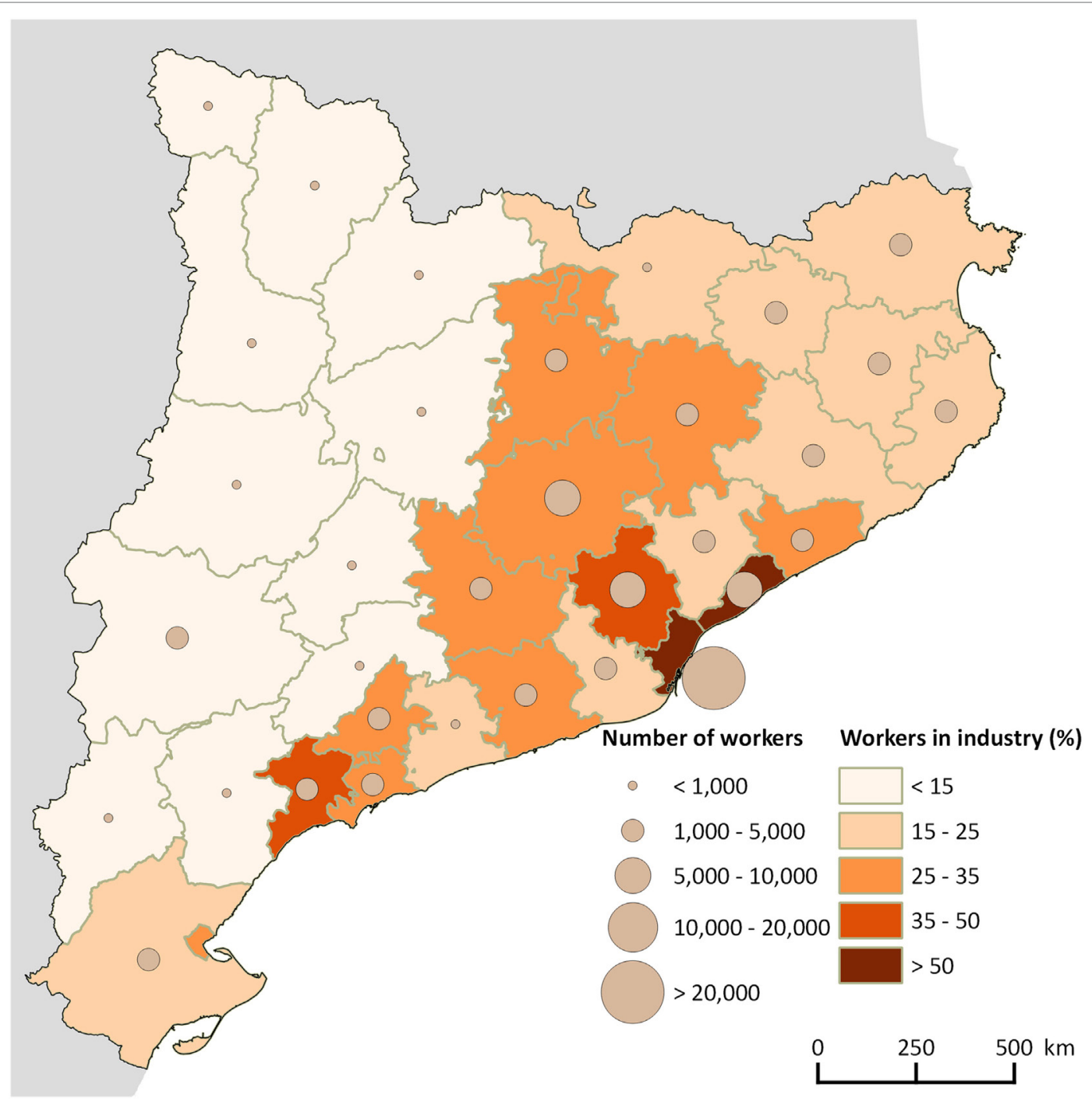

FIGURE 7 | Total and \% of industrial workers over the total occupied population in Catalonia in 1860, by judicial party. This figure does not include artisans. Source: Own research.

because each heritage site is taken as a unit, without measuring the dimensions of each factory. Furthermore, a large number of sites have been destroyed, particularly in the most densely populated urban areas where there was greater pressure to construct on buildable land. For this reason, the number of sites in the agglomeration of Barcelona should have been much greater than the number currently cataloged. Even so, as this was the first time that heritage sites had been geo-located, we observe that the correlation with the 1860 census data is high. This new database has many new possible uses. Its ability to exactly locate elements within a territory allows us to analyze some factors that influence location. In these Figures, we can observe an interesting factor that could help us to explain the distribution of Catalan industry: transport costs. We observed an interesting correlation between railways, commercial port activity and roads, and the distribution of industrial heritage.
The cost advantage associated with maritime and overland transport, both for national and international trade, conditioned the location of settlements. These factors favoring population concentration and the lower associated transport costs fed off each other and acted as a dynamic incentive for industry to progressively accumulate in these areas. These advantages would later become evident, both in terms of a greater supply of specialized labor and in terms of lower transport costs. Even so, there were still some industries spread across the interior and located in the Pyrenees which did not follow the previously described dynamics. Another important factor could be the cause of this outliers industrial heritage locations.

Similarly, Figures $\mathbf{8}$ and $\mathbf{9}$ enable us to show that it is possible to divide Catalonia into two large areas based on its industrial activity. On the one hand, there is the eastern half of the country, which includes the provinces of Barcelona and Gerona and the 


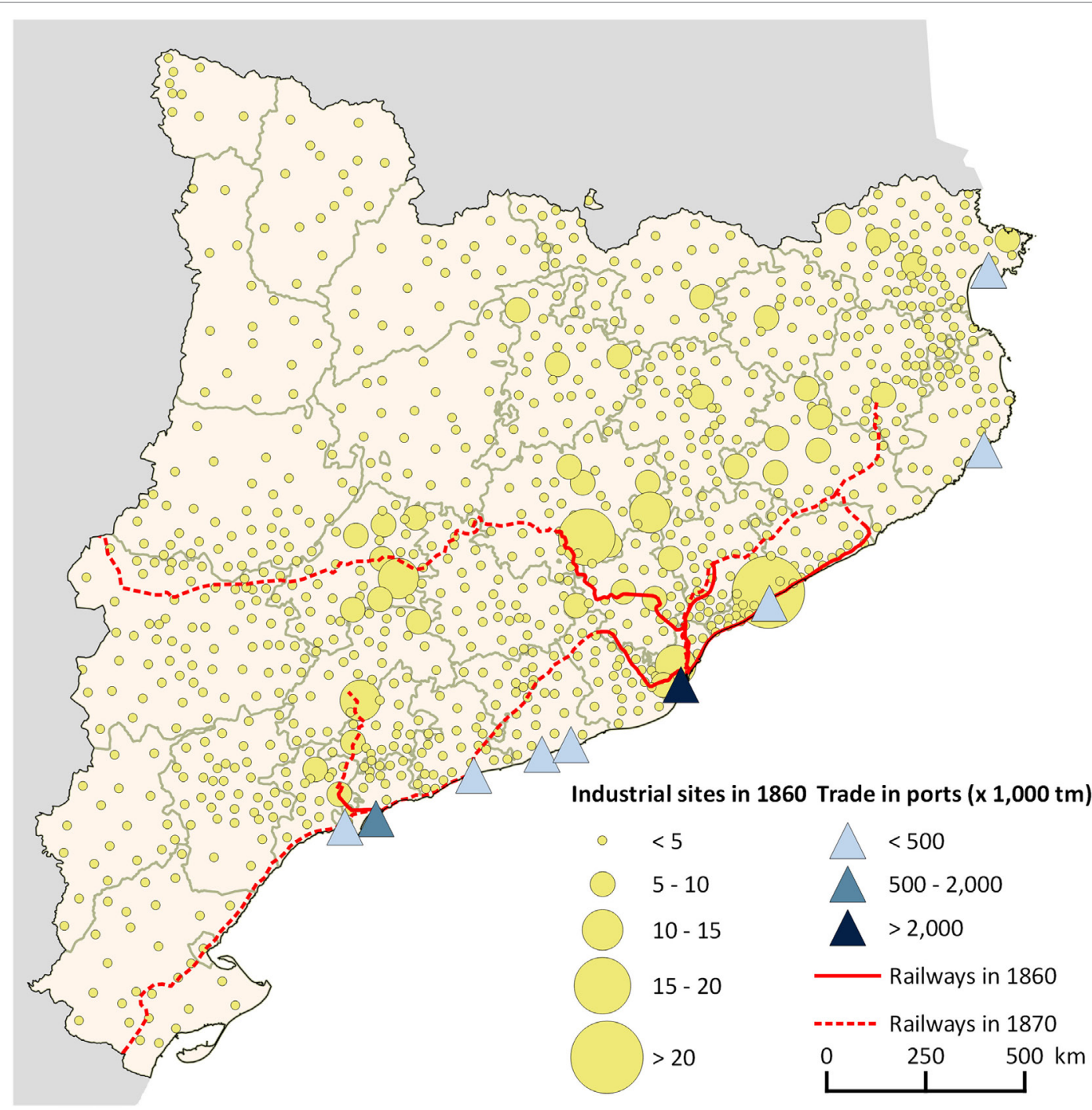

FIGURE 8 | Heritage sites, port and railways in Catalonia in 1860. This figure only include the most relevant ports. Source: Own research.

coastal area of Tarragona. On the other, there is the western half, which exhibits much lower indices of industrial implantation. These same differences are still evident in present-day Catalonia: more than 150 years later. That said, Eastern Catalonia has always been the most populated and urbanized part of the country, and this has been the case since the time of the Roman Empire. Indeed, over the centuries it has benefited from routes following pre-existing routes and in particular, the Vía Augusta, which provided access to ports, with Tarragona being the most important of these. In contrast, western Catalonia had to struggle against the barrier created by the Pyrenees and its distance from the ports. In short, land transport infrastructures helped to consolidate these existing contrasts from 1860 onward, providing preferential service to the areas that already had the greatest densities of population. This is particularly evident in the case of railways (Figure 8), major roads (Figure 9) and river (Figure 10).
The only element of public investment that has helped to improve the integration of Catalan territory can be found in its second and third tier roads, which made it possible to connect large areas of the Catalan interior with other transport services.

Even so, there were some industries that spread across the interior and located in the Pyrenees without following the previously described dynamics. The factor that allows to explain those dynamics is hydrology, as it is possible to appreciate from Figure 8. Water was a key input for both producing energy and as part of the productive process. Certain sectors, such as the paper industry, were totally dependent on an abundant supply of water. Similarly, given the chronic lack of coal in Catalonia, hydraulic power became a reliable alternative. It should also be remembered that the population tended to settle along water courses, so population, and not only water for industrial uses, also played an essential role in industrial location. 


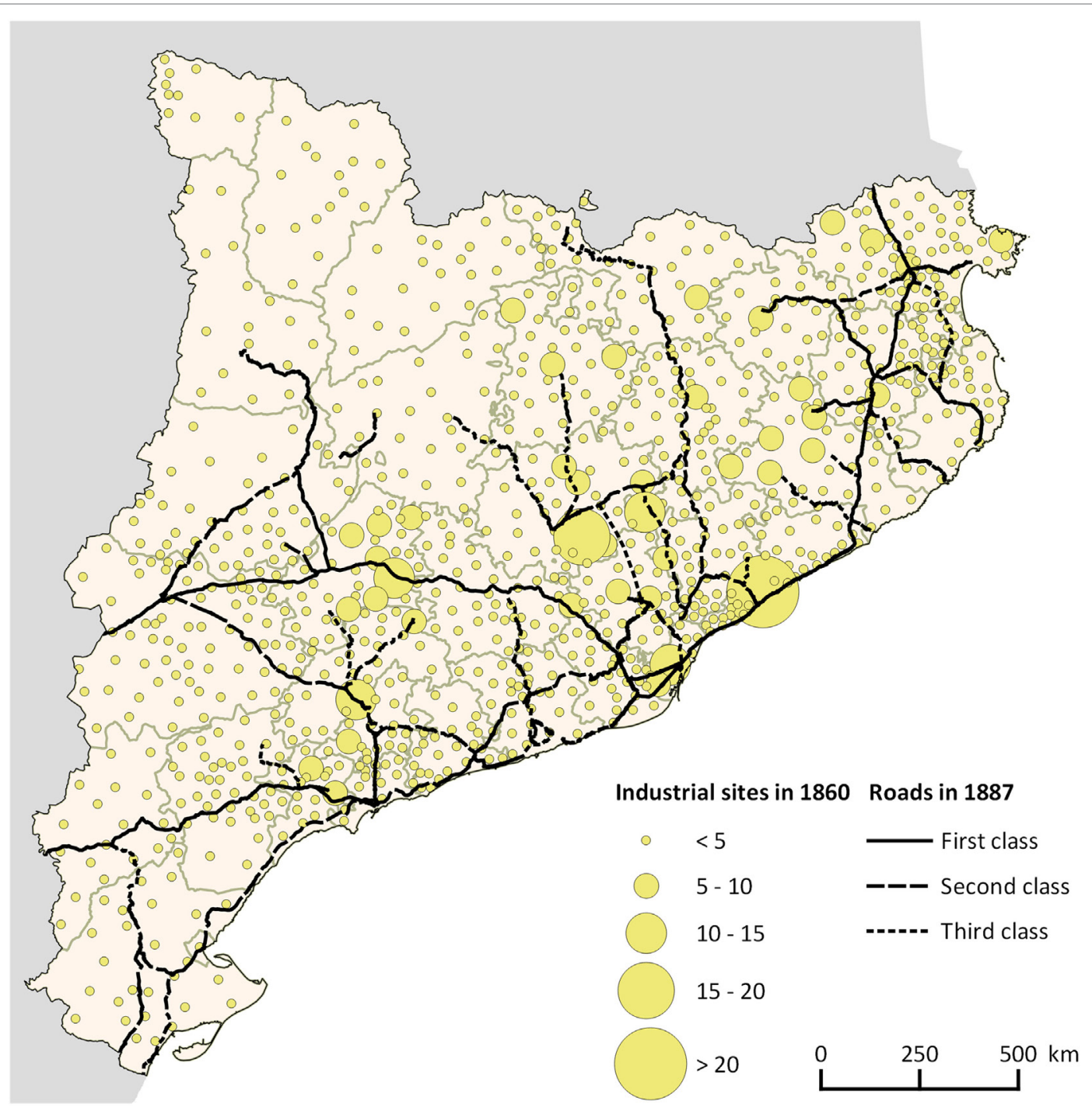

FIGURE 9 | Heritage sites and roads in Catalonia in 1860. Source: Own research.

In conclusion, we observed a great correlation between industrial location and coastal and port factors (especially along the coast near Barcelona), proximity to rivers, and access to forms of overland transport, such as railways and good quality roads.

Finally, a clue obtained from some of our base files (Figure 9) could give us an insight into other uses that could be exploited, apart from integrating all of the data into a website. In this Figure, it is possible to observe three examples that were chosen at random. It is possible to appreciate the type of information available, both in writing and in the form of diagrams. Although the files are in Catalan, they should give the reader an idea of the content.

\section{DISCUSSION}

In this article, we have made a descriptive analysis of the socioeconomic structure of Spain's and Catalan's judicial districts in 1860, based on the census of "Profesiones, artes y oficios." This implied working at a level of territorial disaggregation that was not available again until the census of 1960. This article enriches our knowledge of Spain in the early years of its industrialization and situates Catalonia as what would later come to be known as "the factory of Spain." We think that the geographical and sectorial disaggregation and detail presented here could be of help for future research in a wide variety of fields as economic history, locational studies, economic geography, historical geography, and digital humanities.

In this article, we have verified the hypothesis of the greater presence of industrial sites in the areas in which the 1860 census already highlighted the most intense industrial activity, albeit at only the descriptive level. For the moment, this remains mainly an intuitive conclusion rather than solid evidence. However, the areas which had the greatest densities of population and activity are the ones from which the greatest number of industrial sites have disappeared and, as a result, these have neither been cataloged nor included in our database. The systematic data contained in our 


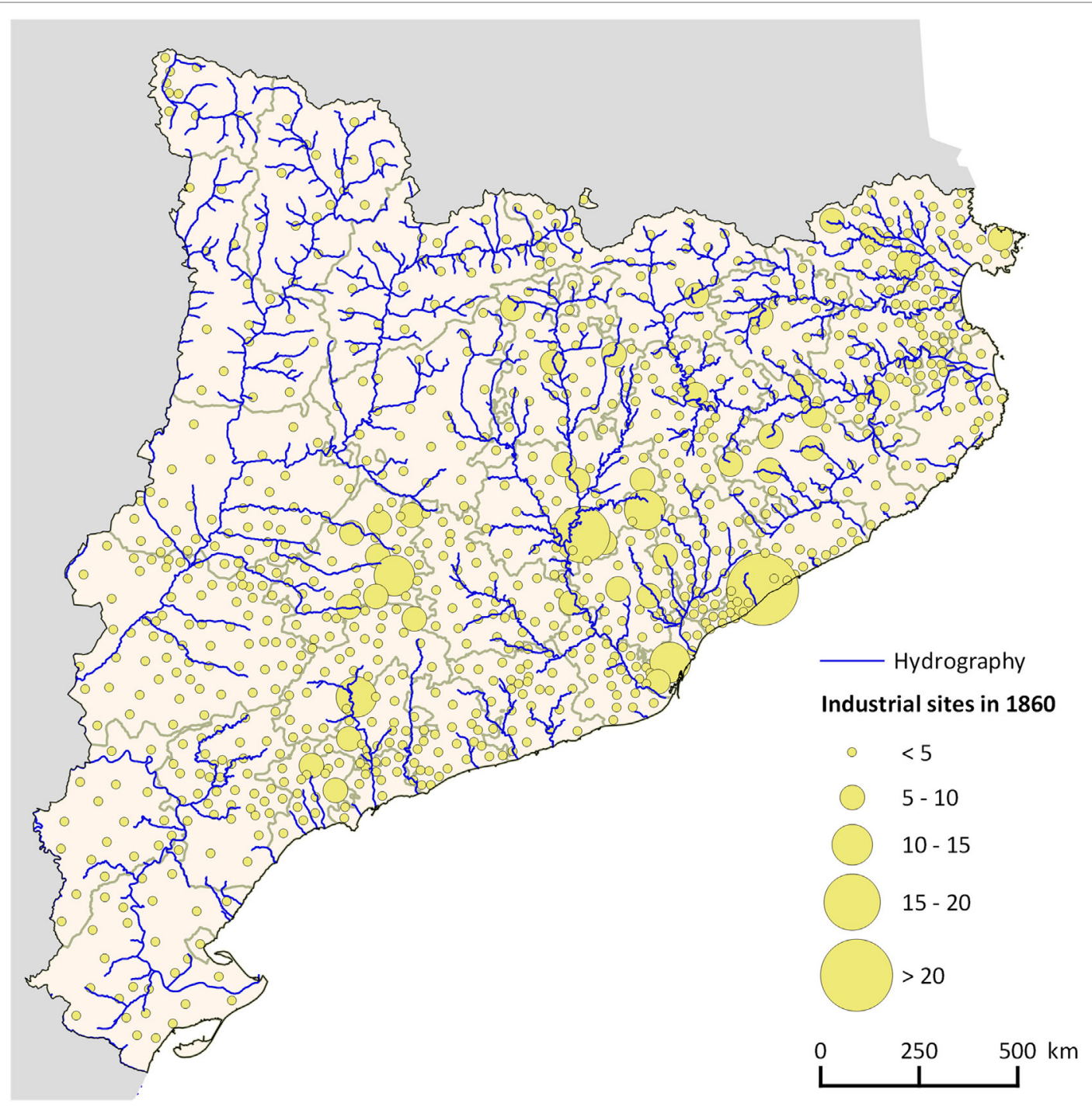

FIGURE 10 | Heritage sites and rivers in Catalonia in 1860. Source: Own research.

database offer various possibilities for the future. One of these is to use data since 1860 to show the evolution of the introduction of manufacturing industry. Second, it will be possible to classify industrial sites according to their activity sector and individual dimensions. Working along these lines, it will be possible to incorporate data from other sources, such as from special newspaper collections relating to the nineteenth century, in digital format.

Recent progress in the field of digital history have made it possible to exploit the repositories of reviews, bibliographies, and newspapers which, from the middle of the nineteenth century onward, were published on a massive scale in Europe. In the case of Catalonia, we have available the digital press library of La Vanguardia ${ }^{20}$ and the Digital Press Library of Spain's National Library. ${ }^{21}$

\footnotetext{
${ }^{20} \mathrm{http}: / /$ www.lavanguardia.com/hemeroteca
}

${ }^{21} \mathrm{http}$ //hemerotecadigital.bne.es/index.vm.
This is the line of work that this article recommends us to follow from now on. This would make it possible to compile a more detailed database about each industrial site (both currently existing and now destroyed or otherwise lost) for an interpretation of the evolution of the economic geography of each of the countries studied. This database will be available at the local level, thus permitting a detailed territorial analysis which has so far been impossible to undertake on account of the lack of available data for the majority of national censuses.

In the field of identifying industrial sites, the work done to date in Catalonia stands out for its evident utility, but there is still a lot of work to be done (Figure 11). We should perhaps cite here the European Route of Industrial Heritage (ERIH), which gathers information about reference industrial monuments and museums in Europe. In the case of Catalonia, it has information about only 11 sites. With the information that we have obtained, we could build a much more detailed map of the industrial heritage of Catalonia that would complement the information provided 


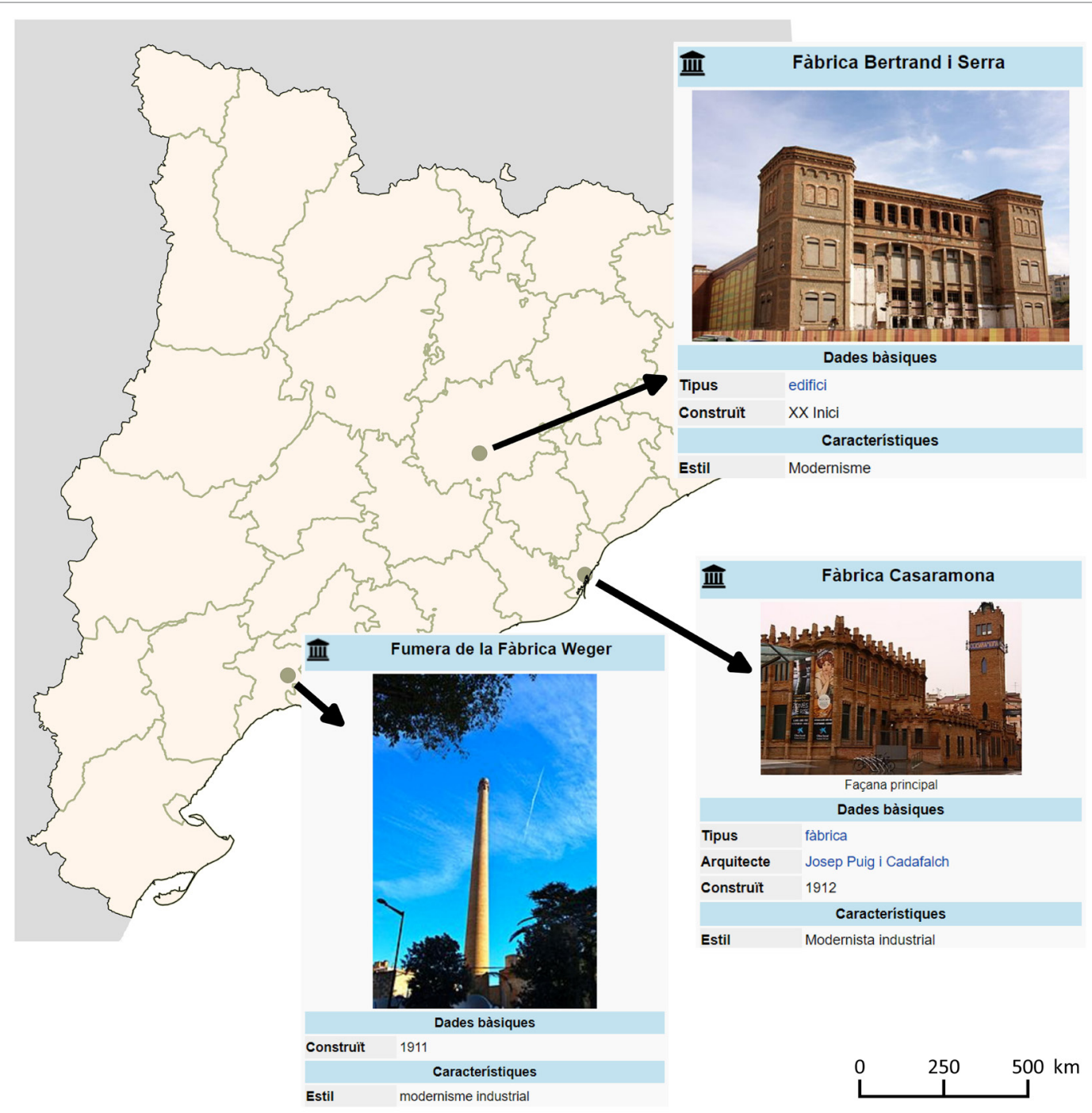

FIGURE 11 | Heritage site database, an example. Source: Own research.

by the ERIH. In fact, our ultimate objective would be to create a "Catalan version" of "Historic England," a public body that looks after England's historic environment and offers detailed information about its industrial heritage through a navigable map. Thanks to the methodology outlined here, this has now become a realistic objective and which we plan to pursue through further research.

\section{AUTHOR CONTRIBUTIONS}

AJ collected and organized the industrial heritage information. GE-O collected and organized the 1860 census information and

\section{REFERENCES}

Ayuda, M.I., Collantes, F., and Pinilla, V. (2010). From locational fundamentals to increasing returns: the spatial concentration of population in Spain, 1787-2000. Journal of Geographical Systems 12: 22-50. doi:10.1007/ s10109-009-0092-x homogenized this article. JM-H designed this text and coordinated throughout the process.

\section{FUNDING}

This research has been financed by the Ministerio de Economía y Competitividad (Spanish Ministry for the Economy and Competitiveness-CSO2015-65733-P), ICREA-Academia and also supported by RecerCaixa, and the EU (Jean Monnet 586912-EPP-1-2017-1-ES-EPPJMO-PROJEC).

Beltrán-Tapia, F., Martínez-Galarraga, J., and Díez-Minguela, A. (2015). Land Access Inequality and Education in Pre-Industrial Spain. Vol. 137. Oxford: Economics Group, Nuffield College, University of Oxford. (No. 137).

Beltrán-Tapia, F., Martínez-Galarraga, J., and Díez-Minguela, A. (2016). Tracing the Evolution of Agglomeration Economies: Spain, 1860-1991. Vol. 1636. Cambridge: Faculty of Economics, University of Cambridge. (No. 1636). 
Comisión Estadística del Reino. (1860). Profesiones, artes y oficios. Available at: http://www.ine.es/inebaseweb/treeNavigation.do?tn=192209

Crafts, N., and Wolf, N. (2014). The location of the UK cotton textiles industry in 1838: a quantitative analysis. The Journal of Economic History 74: 1103-39. doi:10.1017/S0022050714000874

Díez-Minguela, A., Martínez-Galarraga, J., Tirado, D.A., and Sanchís, M.T. (2017). The Origins of Economic Growth and Regional Income Inequality in South-West Europe 1870-1950, Vol. 24544. Madrid: Universidad Carlos III, Instituto Figuerola (No. WP 17-05).

Elden, S. (2007). Governmentality, calculation, territory. Environment and Planning D: Society and Space 25: 562-80. doi:10.1068/d428t

Esteban-Oliver, G. (2017). La distribución geográfica de la actividad económica y de la industria en España: un análisis a nivel de partido judicial, en base al censo de 1860. Biblio3W. Revista Bibliográfica de Geografía y Ciencias Sociales [En línea], Vol. XXII. Barcelona: Universidad de Barcelona (No. 1.209).

Germán, L. (2001). Historia económica regional de España. Siglos XIX y XX. Barcelona: Crítica.

Gozálvez, V., and Martín-Serrano, G. (2016). El censo de la población de España de 1860. Problemas metodológicos. Inicio de la aportación social en los censos. Boletín de La Asociación de Geógrafos Españoles 70: 329-70. doi:10.21138/bage.2174

Kuznets, S. (1955). Economic growth and income inequality. The American Economic Review 45: 1-28.

Martínez-Galarraga, J. (2012). The determinants of industrial location in Spain, 1856-1929. Explorations in Economic History 49: 255-75. doi:10.1016/j. eeh.2011.05.012

Martínez-Galarraga, J., Rosés, J.R., and Tirado, D.A. (2015). The long-term patterns of regional income inequality in Spain, 1860-2000. Regional Studies 49: 502-17. doi:10.1080/00343404.2013.783692

Melón, A. (1951). Los censos de la población en España (1857-1940). Madrid: Estudios Geográficos.

Muro, J., Nadal, F., and Urteaga, L. (1996). Geografía, estadística y catastro en España: 1856-1870. Barcelona: E. del Serbal.

Nadal, J. (1975). El fracaso de la revolución industrial en España, 1814-1913. Barcelona: Ariel.

Ohlin, B. (1933). Interregional and International Trade. Cambridge: Harvard University Press.

Parejo, A. (2004). La industrialización de las regiones españolas durante la primera y la segunda revolución tecnológica. Andalucía, Cataluña, País Vasco
(1830-1975). Revista de Historia Económica, Año XXII o 669-705. Available at: http://e-archivo.uc3m.es/handle/10016/2781

Pons, J., Paluzie, E., Silvestre, J., and Tirado, D.A. (2007). Testing the new economic geography: migrations and industrial agglomerations in Spain. Journal of Regional Science 47: 289-313. doi:10.1111/j.1467-9787.2007.00510.x

Prados de la Escosura, L. (2003). El progreso económico de España (1850-2000). Bilbao: Fundación BBVA.

Randeraad, N. (2011). The international statistical congress (1853-1876): knowledge transfers and their limits. European History Quarterly 41: 50-65. doi:10.1177/0265691410385759

Rosés, J.R., Martínez-Galarraga, J., and Tirado, D.A. (2010). The upswing of regional income inequality in Spain (1860-1930). Explorations in Economic History 47: 244-57. doi:10.1016/j.eeh.2010.01.002

Silvestre, J. (2007). Temporary internal migrations in Spain, 1860-1930. Social Science History 31: 539-74. doi:10.1017/S0145553200013857

Tirado, D.A., Díez-Minguela, A., and Martinez-Galarraga, J. (2016). Regional inequality and economic development in Spain, 1860-2010. Journal of Historical Geography 54: 87-98. doi:10.1016/j.jhg.2016.09.005

Tirado, D.A., Paluzie, E., and Pons, J. (2002). Economic integration and industrial location: the case of Spain before World War I. Journal of Economic Geography 2: 343-63. doi:10.1093/jeg/2.3.343

Tortella, G. (1995). Los orígenes del capitalismo en España: banca, industria y ferrocarriles en el siglo XIX. Madrid: Tecnos.

Williamson, J.G. (1965). Regional inequality and the process of national development: a description of the patterns. Economic Development and Cultural Change 13(4, Part 2): 1-84. doi:10.1086/450136

Conflict of Interest Statement: The authors declare that the research was conducted in the absence of any commercial or financial relationships that could be construed as a potential conflict of interest.

Copyright (C) 2017 Esteban-Oliver, San José and Martí-Henneberg. This is an open-access article distributed under the terms of the Creative Commons Attribution License (CC BY). The use, distribution or reproduction in other forums is permitted, provided the original author(s) or licensor are credited and that the original publication in this journal is cited, in accordance with accepted academic practice. No use, distribution or reproduction is permitted which does not comply with these terms. 